\title{
INTERRELATION OF PROFESSIONAL AND PSYCHOLOGICAL CULTURE AND PSYCHOLOGICAL WELL-BEING OF FUTURE SOCIAL WORKERS
}

У статті проаналізовано сутнісний зміст феномену психологічного благополуччя в контексті переживання індивідом повноти самореалізації, що виражається у задоволеності власним життям і собою; наведено його складники. Охарактеризовано поняття соціальної роботи як міждисциплінарної галузі знань і практичної діяльності. Визначено, що соціальний працівник - це професійно підготовлений фахівець, який надає соціальні послуги, спрямовує свою діяльність на активізацію саморозвитку і самоорганізаuії особистості, групи, колективу. Наведено узагальнене визначення професійно-психологічної культури соціального працівника як багатокомпонентної структури, інтегративної властивості фрахівця, що виступає одним із основних показників його особистісного і профресійного розвитку. Виділено такі структурні компоненти професійно-психологічної культури соціального працівника: ціннісно-смисловий, реслексивно-регулятивний, емоційний і комунікативний, а також їі відповідні фуункції. Описано методики дослідження професійно-психологічної культури, психологічного благополуччя й особливості їх застосування. Проаналізовано результати емпіричного дослідження, в якому встановлено у майбутніх соціальних працівників характер кореляційних взаємозв'язків між показниками професійно-психологічної культури (такими як психологічні цінності; любов до людей; рефрлексія; конструктивне професійне спілкування; профресійно-психологічна спрямованість; гармонізуючий саморозвиток; самоаналіз, самопізнання; конструктивність профресійної діяльності, відповідальність; інтелектуальні прагнення; психічна саморегуляція; творчість) і психологічного благополуччя (позитивні стосунки, автономія, керування середовищем, особистісне зростання, иілі в житті, самоприйняття). Зазначається, що компоненти професійно-психологічноі культури соціального працівника та складники психологічного благополуччя органічно взаємопов'язані, а міжкомпонентні зв'язки взаємозалежні.

Ключові слова: професійно-психологічна культура, майбутній соціальний працівник, психологічне благополуччя, саморозвиток, саморегуляція, рефрексія, особистісне зростання, самоприйняття, позитивні стосунки.

The article analyzes the essential content of the phenomenon of psychological well-being in the context of an individual's experience of fullness of self-realization, expressed in satisfaction with his own life and himself; its components are given. The concept of social work as an interdisciplinary field of knowledge and practical activity is characterized. It is determined that a social worker is a professionally trained specialist who provides social services, directs his activities to activate self-development and self-organization of an individual, group, or team. A generalized definition of the professional and psychological culture of a social worker as a multi-component structure, an integrative property of a social worker, which acts as one of the main indicators of his personal and professional development, is given. The following structural components of the professional and psychological culture of a social worker are identified: value-semantic, reflexive-regulatory, emotional and communicative, as well as its corresponding functions. Methods of research of professional and psychological culture, psychological well-being and features of their application are described. The results of an empirical research are analyzed, which established nature of correlation relationships of future social workers between indicators of professional and psychological culture (psychological values; humanism; reflection; constructive professional communication; professional psychological orientation; harmonizing self-development; introspection, self-knowledge; constructiveness of professional activity, responsibility; intellectual aspirations; mental self-regulation; creativity) and psychological well-being (positive relationships, autonomy, surroundings control, personal growth, life goals, self-acceptance). It is noted that the components of the professional and psychological culture of a social worker and the components of psychological well-being are organically interrelated, and inter-component connections are interdependent.

Key words: professional-psychological culture, future social worker, psychological well-being, self-development, self-regulation, reflection, personal growth, self-acceptance, positive relationships.
Чтарший викладач кафедри пс

університет імені Петра Могили
Постановка проблеми. Особливості кризових процесів сучасного українського суспільства за умов посилення соціально-економічного напруження призвели до загострення проблем у сфері вищої освіти, що особливо стосується підготовки фахівців соціономічного профілю. Високий рівень професійно-психологічної культури сприяє ефективності діяльності у психотравмуючих професійних ситуаціях, збереженню психічних і фізіологічних резервів, стійкості до впливу психоемоційних стресорів і $є$ необхідною умовою забезпечення психологічного здоров'я та благополуччя майбутніх соціальних працівників. Вивчення цієї проблеми має не лише соціальну та наукову актуальність, а й при- 
кладне значення в напрямі підготовки фахівців соціальної сфери високого ґатунку.

Аналіз останніх досліджень і публікацій. Проблема психологічного благополуччя розглядається у працяхК. Ріфф, П. П. Фесенко, Т.Д. Шевеленкової, Н.В. Гранкіної-Сазонової та ін. Вивченням особливостей розвитку професійно-психологічної культури працівників освіти (педагогів, викладачів, майбутніх вчителів) займалися: В.О. Аристова, О.Г. Видра, О.В. Винославська, Н.І. Мачинська, Н.Ю. Певзнер, Н.В. Пророк, В.В. Семикін; практичних психологів: Н.І. Волошко, Н.І. Ісаєва, П.С. Перепелиця, С.К. Шандрук; учнівської молоді: І.Г. Євстаф'єва, В.В. Рибалка, О.А. Рудомьоткіна, Т.Б. Тарасова та ін. Натомість досліджень, які хоча б частково охоплюють питання професійно-психологічної культури безпосередньо соціальних працівників, вкрай мало (О.О. Кісенко, З.Л. Становських), а її взаємозв'язку із психологічним благополуччям - практично відсутні. Актуальність і недостатня вивченість проблеми зумовлюють мету статті - проаналізувати взаємозв'язок між показниками професійно-психологічної культури та психологічного благополуччя у майбутніх соціальних працівників.

Виклад основного матеріалу дослідження. Психологічне благополуччя розглядається науковцями в контексті переживання індивідом цілісності й осмисленості власного життя, відчуття повноти самореалізації. Так, згідно з концепцією К. Ріфф психологічне благополуччя визначається як базовий особистісний конструкт, який виступає показником суб'єктивного сприйняття й оцінки власної життєдіяльності крізь призму використання вершинних потенційних можливостей людини $[12$, c. 367].

У свою чергу, П.П. Фесенко і Т.Д. Шевеленкова розуміють психологічне благополуччя як інтегральну характеристику досягнення особистістю позитивного функціонування, що відображає одночасно наявні та потенційні аспекти її життєдіяльності та виражається у задоволеності власним життям і собою [11, с. 102]. «Позитивне» (повноцінне, ефективне) функціонування включає в себе точність сприйняття реальності, адаптивну поведінку (здатність справлятися зі стресовими ситуаціями, успішне вирішення проблем), позитивну самомотивацію, смисли та цілі, цінності особистісного зростання, свободи, відповідальності, зв'язку з іншими людьми тощо [3, с. 25, 26].

Досягнення благополуччя неможливе без високого рівня професійно-психологічної культури, яка передбачає найвищий розвиток потенційних можливостей індивіда. Професійно-психологічну культуру у цій роботі розглядаємо як самостійний багатовимірний психологічний феномен, комплексне інтегративне особистісне утворення, що становить цілісну сукупність взаємопов'язаних психологічних властивостей (мотиваційних, емоційних, рефлексивних, регулятивних), заснованих на гуманістично орієнтованому ціннісно-смисловому аспекті (системі професійно-значущих ціннісних орієнтацій і смислів), розвиненій рефлексії та продуктивному саморозвитку. Вона виступає осереддям структури професійно важливих якостей, забезпечує високий рівень саморегуляції, ефективності соціальної взаємодії та успішності професійної діяльності [5, с. 50].

Професія соціального працівника за психологічним змістом праці належить до типу «людина-людина» (соціономічні професії), що передбачає роботу із соціальними системами, колективами, соціально-віковими групами, людьми, котрі перебувають у критичному стані або потребують невідкладної професійної допомоги [6]. Визначено, що соціальний працівник - це професійно підготовлений фахівець, який має необхідну кваліфікацію у сфері соціальної роботи та надає соціальні послуги, спрямовує свою діяльність на стимулювання саморозвитку і самоорганізації особистості, групи, колективу, створення умов для активізації цього розвитку і реалізації творчого потенціалу своїх підопічних [10, с. 60-61]. Вирішення зазначених вимог можливе за рахунок реалізації професійно-психологічної культури, яка забезпечує успішну роботу соціального працівника з людьми, що перебувають у складних життєвих обставинах.

Як структурні складники професійно-психологічної культури соціального працівника нами виділено ціннісно-смисловий, рефлексивно-регулятивний, емоційний і комунікативний компоненти [5, с. 54].

Ціннісно-смисловий компонент є сукупністю гуманістичних ціннісних орієнтацій, що виражає ставлення до світу, людей, власної діяльності та включає в себе показники: погляд на природу людини, любов до людей; спрямованість, ціль у житті; психологічні цінності; мотивація самопізнання; інтелектуальні прагнення; творча спрямованість, креативність і наявність власної життєвої філософії. Рефлексивно-регулятивний компонент професійно-психологічної культури відображає високий рівень довільного управління внутрішньою та зовнішньою активністю для досягнення значимої мети на основі рефлексивних механізмів, завдяки яким майбутній фахівець має можливість усвідомити власні особистісно-професійні характеристики. Вказаний компонент проявляється у таких показниках, як: саморозвиток, особистісне зростання; рефлективність; відповідальність; саморегуляція; автономність, опора на себе та самоприйняття. 
Емоційний компонент розглядається як здатність до управління емоціями, регулювання власної поведінки в різних ситуаціях, що проявляється у психологічній стійкості до емоційного впливу, стресостійкості, емоційній врівноваженості, сприяе психологічно конструктивному розв'язанню особистісно-професійних задач і поєднує між собою такі показники, як: самомотивація довільного управління власними емоціями; емоційна обізнаність; емпатійність; емоційна гнучкість; глибинність переживань і розпізнавання емоцій інших людей. У свою чергу, до основних складників комунікативного компоненту професійно-психологічної культури, що сприяють ефективній соціальній взаємодії та продуктивним взаємовідносинам, належать: контактність; толерантність; комунікативний потенціал особистості; поведінкова гнучкість; позитивні стосунки з іншими; конструктивність професійного спілкування; рефлексія спілкування і взаємодії з іншими людьми [4, с. 43-45].

Варто зазначити, що, як і в більшості психологічних структур, виділення вказаних компонентів професійно-психологічної культури соціального працівника та їхніх показників (серед яких представлено і показники психологічного благополуччя) $€$ досить умовним, оскільки психологічні феномени, які становлять їх сутність, органічно взаємопов'язані, а міжкомпонентні зв'язки взаємозалежні. Дослідники виділяють такі функції професійно-психологічної культури соціальних працівників: ціннісна, мотивувальна, креативна, регулятивна, рефлексивна, розвивальна, емотивна, гармонізуюча, інтегративна, комунікативна, адаптивна та фасилітативна [7, с. 23; 8; 9, с. 13].

В емпіричному дослідженні показників професійно-психологічної культури та психологічного благополуччя взяли участь студенти спеціальності «Соціальна робота» 1-5 курсів навчання Чорноморського національного університету імені Петра Могили (м. Миколаїв), Миколаївського національного університету імені В.О. Сухомлинського та Херсонського державного університету загальною кількістю 366 осіб віком 17-23 років.

У дослідженні було використано методику «Психологічна культура особистості» О.І. Моткова (модифікація О.Г. Видри) та «Шкала психологічного благополуччя» К. Ріфф (адапт. Т.Д. Шевеленкова, П.П. Фесенко). Зупинимося детальніше на їх характеристиці.

Модифікований О.Г. Видрою варіант методики «Психологічна культура особистості» O.I. Моткова [2, с. 208-214] побудований як семантичний опитувальник, що включає 55 тверджень, кожне з яких оцінюється за допомогою балів: 5 - «для мене це дуже важливо»; 4 - «важливо»; 3 - «має певне значення»; 2 - «має невелике значення»; 1 - «не має ніякого значення» за двома п'ятибальними шкалами: шкала А - оцінка сили культурно-психологічного прагнення, шкала Б - оцінка ступеня його реалізації студентом в особистісно-професійній діяльності.

Методика містить такі шкали: психологічні цінності; любов до людей; творчість; спрямованість; конструктивне професійне спілкування; самоаналіз, самопізнання; інтелектуальні прагнення; рефлексію; психічну саморегуляцію; гармонізуючий саморозвиток; конструктивність професійної діяльності, любов до праці, відповідальність.

Обробка результатів здійснюється відповідно до ключа [2, с. 213]: 1) по шкалі А підраховується середнє арифметичне відповідей за силою прагнення кожного виду; 2) визначається середнє арифметичне відповідей по шкалі А на всі питання 1-55, що показує середню міру виразності у студента всіх прагнень професійно-психологічної культури загалом; 3) аналогічно по шкалі Б визначається середня міра виразності у студента ступеня реалізації кожного виду психологічного прагнення та професійно-психологічної культури загалом. Пріоритетними є показники ступеня реалізації психологічного прагнення та психологічної культури загалом (за шкалою Б). У свою чергу, визначаються рівні виразності сили та ступеня реалізації культурно-психологічних прагнень: елементарний, базовий, досконалий і псевдовисокий (уведений О.Г. Видрою для фіксування неадекватно завищених самооцінок студентів або хибних відповідей) [2, с. 214].

Опитувальник «Шкала психологічного благополуччя» К. Ріфф (адапт. Т.Д. Шевеленкова, П.П. Фесенко) складається із 84 тверджень, за кожним із яких досліджуваному пропонується виразити ступінь своєї згоди таким чином: абсолютно не згоден (1 бал у прямих твердженнях, 6 балів - у зворотних); не згоден (2 бали у прямих твердженнях, 5 балів - у зворотних); швидше не згоден (3 бали у прямих твердженнях, 4 бали - у зворотних); швидше згоден (4 бали у прямих твердженнях, 3 бали - у зворотних); згоден (5 балів у прямих твердженнях, 2 бали у зворотних) та абсолютно згоден (6 балів у прямих твердженнях, 1 бал - у зворотних). Підрахунок балів за основними шістьма шкалами (такими як позитивні стосунки, автономія, керування середовищем, особистісне зростання, цілі у житті, самоприйняття) та психологічним благополуччям відбувається відповідно до ключа, після чого здійснюється інтерпретація результатів. Загальний показник психологічного благополуччя має такі рівні вираженості: 0-323 балів - низький рівень; 324-353 балів - середній рівень; 
354 та більше балів - високий рівень психологічного благополуччя [11].

Метою вказаного дослідження було здійснення кореляційного аналізу для встановлення співвідношення показників професійно-психологічної культури та психологічного благополуччя, тобто визначення, які з досліджуваних показників найбільш тісно пов'язані між собою. Ми виходили з міркування про те, що окреслення характеру цих взаємозв'язків дозволить визначити властивості особистості, які сприятимуть або, навпаки, гальмуватимуть розвиток професійно-психологічної культури. Такі результати мають послужити основою для розкриття специфіки факторів, які необхідно враховувати при побудові системи розвитку професійно-психологічної культури.

Для перевірки теоретичного конструкту професійно-психологічної культури та ії основних компонентів був застосований кореляційний аналіз, який надає можливість точної кількісної оцінки ступеня узгодженості змін (варіювання) двох і більше ознак. Слід зазначити, що значимий коефіцієнт кореляцій між двома ознаками свідчить лише про наявність зв'язку, але не про причинно-наслідкову залежність між ознаками, тобто каузальність [1]. Отже, кореляційний аналіз дасть можливість проаналізувати кореляційні зв'язки між показниками професійно-психологічної культури та показниками психологічного благопо- луччя, що гіпотетично взаємопов'язані з нею. Процедура обробки даних проводилася за допомогою пакету програмного забезпечення SPSS 21.0 for Windows.

Для виявлення співвідношення між професійно-психологічною культурою та психологічним благополуччям проаналізуємо значимі кореляційні зв'язки між їх показниками, результати кореляційного аналізу наведено в таблиці.

Як видно з таблиці, загальний показник психологічної культури (ЗПК) виявив додатні зв'язки на $1 \%$ рівні з показником позитивних стосунків (ПС), показником керування середовищем (КС) та на 5\% рівні - з показниками особистісного зростання (ОЗ) та самоприйняття (Спр). Показник психологічних цінностей (ПЦ) виявив додатний зв'язок із показниками позитивних стосунків (ПС) та цілей в житті (ЦЖ) на 1\% рівні. Показник любові до людей (ЛДЛ) додатно пов'язаний із показниками керування середовищем (КС), особистісного зростання (О3), самоприйняття (Спр) на $1 \%$ рівні та на $5 \%$ рівні - із загальним показником психологічного благополуччя (ЗПБ).

Показник рефлексії (Реф) виявив від'ємний зв'язок на $5 \%$ рівні з показниками позитивних стосунків (ПС), автономії (Ав) і додатний зв'язок із показником самоприйняття (Спр) на $1 \%$ рівні. Показник культурного, конструктивного, професійного спілкування (КСп) має додатний

\section{Значимі коефіцієнти кореляції між показниками психологічної культури та психологічного благополуччя}

\begin{tabular}{|l|l|l|l|l|l|l|l|}
\hline \multirow{2}{*}{$\begin{array}{l}\text { Показники } \\
\text { кульл. }\end{array}$} & \multicolumn{2}{|l}{ Показники } \\
\cline { 2 - 8 } & ПС & Ав & КС & ОЗ & ЦЖ & Спр & ЗПБ \\
\hline ЗПК & $276^{\star}$ & & $187^{\star \star}$ & $155^{\star}$ & 109 & $161^{\star}$ & 123 \\
\hline ПЦ & $231^{\star}$ & -102 & & & $238^{\star}$ & & \\
\hline ЛДЛ & & & $170^{\star}$ & $153^{\star}$ & 139 & $108^{\star}$ & 133 \\
\hline Реф & -122 & $-222^{\star}$ & & & & $209^{\star}$ & \\
\hline КСп & $-175^{\star}$ & 128 & 127 & & $207^{\star}$ & $201^{\star}$ & \\
\hline$П П С ~$ & $-188^{\star}$ & $-225^{\star}$ & & $-181^{\star}$ & $-263^{\star}$ & & -234 \\
\hline ГСр & $-364^{\star}$ & & $185^{\star}$ & $398^{\star}$ & 131 & $175^{\star}$ & 125 \\
\hline СА & $-261^{\star}$ & $-324^{\star}$ & & & $-162^{\star}$ & & \\
\hline КПД & $-141^{\star}$ & & $182^{\star}$ & $161^{\star}$ & & $281^{\star}$ & 129 \\
\hline ІПр & & $-219^{\star}$ & 111 & & & 135 & $266^{\star}$ \\
\hline$П С р$ & & & $152^{\star}$ & 121 & & $152^{\star}$ & $385^{\star}$ \\
\hline Тв & & & 105 & 132 & & 106 & $328^{\star}$ \\
\hline
\end{tabular}

Примітки: 1) коми та нулі опущено; 2) позначка «^» кореляція на 1\% рівні; без позначки - кореляція на 5\% рівні; 3) умовні скорочення показників психологічної культури: ЗПК - загальний показник психологічної культури; ПЦ психологічні цінності, лДЛ - любов до людей; Реф - рефлексія; КСп - культурне, конструктивне, професійне спілкування; ППС - професійно-психологічна спрямованість; ГСр - гармонізуючий саморозвиток; СА - самоаналіз, самопізнання; КПД - конструктивність професійної діяльності, любов до праці, відповідальність; ІПр інтелектуальні прагнення; ПСр - психічна саморегуляція; Тв - творчість; умовні скорочення показників психологічного благополуччя: ПС - позитивні стосунки, Ав - автономія, КС - керування середовищем, ОЗ - особистісне зростання, ЦЖ - цілі в житті, Спр - самоприйняття, ЗПБ - загальний показник психологічного благополуччя. 
зв'язок на 1\% рівні з показниками цілей у житті (ЦЖ), самоприйняття (Спр) та від'ємний зв'язок із показником позитивних стосунків (ПС). Отримано від'ємні зв'язки на 1\% рівні між показником професійно-психологічної спрямованості (ППС), позитивних стосунків (ПС), автономії (Ав), особистісного зростання (ОЗ) і загальним показником психологічного благополуччя (ЗПБ).

Показник гармонізуючого саморозвитку (ГСр) виявив додатний зв'язок на $1 \%$ рівні з показниками керування середовищем (KC), особистісного зростання (ОЗ), самоприйняття (Спр), цілей у житті (ЦЖ) і загальним показником психологічного благополуччя (ЗПБ), від'ємний зв'язок із показником позитивних стосунків (ПС). Показник самоаналізу, самопізнання (СА) виявив від'ємний зв'язок на 1\% рівні з показниками позитивних відносин (ПВ), автономії (Ав) та цілей в житті (ЦЖ) на 5\% рівні. Показник конструктивності професійної діяльності, любові до праці, відповідальності (КПД) виявив 1\% додатний зв'язок 3 показниками керування середовищем (КС), особистісного зростання (О3).

Показник інтелектуальних прагнень (IПр) виявив від'ємний зв'язок із показником автономії (Ав) на $1 \%$ рівні, додатний зв'язок із показниками самоприйняття (Спр) на 5\% рівні та загальним показником психологічного благополуччя (ЗПБ) на $1 \%$ рівні. Показник психічної саморегуляції (ПСр) додатно пов'язаний з показниками керування середовищем (КC), особистісного зростання (ОЗ), самоприйняття (Спр) на 5\% рівні та загальним показником психологічного благополуччя (ЗПБ) на $1 \%$ рівні. Показник творчості (Тв) додатно пов'язаний із показниками особистісного зростання (O3) на $5 \%$ рівні та з загальним показником психологічного благополуччя (ЗПБ) на 1\% рівні.

Отримані результати свідчать про те, що показники професійно-психологічної культури майбутніх соціальних працівників виявили значимі кореляційні зв'язки з показниками їх психологічного благополуччя.

Висновки 3 проведеного дослідження. Кореляційний аналіз підтвердив передбачувані зв'язки між показниками професійно-психологічної культури (такими як психологічні цінності; любов до людей; рефлексія; конструктивне професійне спілкування; професійно-психологічна спрямованість; гармонізуючий саморозвиток; самоаналіз, самопізнання; конструктивність професійної діяльності, відповідальність; інтелектуальні прагнення; психічна саморегуляція; творчість) і психологічного благополуччя (позитивні стосунки, автономія, керування середовищем, особистісне зростання, цілі в житті, самоприйняття). Характер зазначених зв'язків визначив складність феноменів, що вивчаються, його неод- нозначність у взаємодії з окресленими психологічними властивостями особистості. За результатами отриманих кореляцій проаналізовано та інтерпретовано дані, які будуть взяті за основу визначення рівнів професійно-психологічної культури студентів - майбутніх фахівців соціономічних професій із метою організації системи її ефективного становлення за умов університету, що є перспективним напрямом подальших досліджень.

\section{ЛIТЕРАТУРА:}

1. Бурлачук Л.Ф. Словарь-справочник по психодиагностике. Санкт-Петербург : Питер, 2007. 528 с

2. Видра О.Г. Психологічна культура майбутніх вчителів трудового навчання: дослідження та розвиток. Розвиток психологічної культури учнівської молоді в системі неперервної профеесійної освіти : навчально-методичний посібник / ред. В.В. Рибалки. Київ : ІПППО АПН України, 2005. С. 206-221.

3. Гранкіна-Сазонова Н.В. Психологічне благополуччя та життєстійкість студентів-психологів як важливі чинники освоєння профресії. Psychological journal. 2018. № 7. C. 23-42.

4. Гусак В.М. Структурно-фрункціональна модель просресійно-психологічної культури соціального працівника. Теорія і практика сучасної психології: збірник наукових пращь. Запоріжжя, 2019. № 5. Т. 2. С. 41-47.

5. Гусак В.М. Формування професійно-психологічної культури майбутніх соціальних працівників в умовах університетської освіти : дис. ... канд. психол. наук : 19.00.07 / Чорноморський національний університет ім. П. Могили. Миколаїв, 2020. 264 с.

6. Климов Е.А. Психология профессионала. Москва : «Институт практической психологии». 1996. $400 \mathrm{c}$.

7. Особливості формування психологічної культури працівників освіти в інфрормаційному суспільстві : монографрія / ред. Н.В. Пророк. Київ : Видавничий Дім «Слово», 2017. 200 с.

8. Пророк Н.В. Внутрішні передумови психологічної культури працівників освіти. Перспективні питання психолосії : збірник наукових праць / за матеріалами всеукр. наук.-практ. інтернет-конфр. «Проблема особистісної активності в освітньому просторі: концептуальний, методологічний та емпіричний аспекти» (м. Слов'янськ, 2017 р.). Слов'янськ : ДВН3 «Донбаський державний педагогічний університет», 2017. С. 124-132.

9. Семикин В.В. Психологическая культура в педагогическом взаимодействии : автореф. дис. ... докт. психол. наук : 19.00.07 / Российский государственный педагогический университет им. А.И. Герцена. Санкт-Петербург, 2004. 48 с.

10. Синявський В.В. Професіограми і психограми профеесій педагогічного спрямування : методичний посібник. Київ : Інститут педагогічної освіти і освіти дорослих НАПН України, 2013. 97 с.

11. Шевеленкова Т.Д., Фесенко П.П. Психологическое благополучие личности (обзор основных концепций и методика исследования). Психологическая диагностика. 2005. № 3. С. 95-123.

12. Ryff C.D. Psychological well-being. Encyclopedia of Gerontology. 1996. Vol. 2. P. 365-369. 